\section{Phomopsidin, a New Inhibitor of Microtubule Assembly Produced by Phomopsis sp. Isolated from Coral Reef in Pohnpei}

Sir:

Antimitotic natural products, such as taxol, ansamitocin P-3, vinblastine, and griseofulvin, are useful antitumor and antifungal agents. Recently, curacin A, which is a potential antitumor agent, was isolated from marine cyanobacterium (blue-green alga) Lyngbya majuscula as an antimitotic cytotoxic component. ${ }^{1}$ We have reported an effective assay method for antimitotic substances, which observes deformations of mycelia germinated from conidia of Pyricularia oryzae $\mathrm{P}-2 \mathrm{~b}$, and certain antimitotic compounds can be detected by the characteristic curling effect of the mycelia. ${ }^{2)}$ Curacin A, which inhibits the assembly of microtubule proteins, showed the curling effect.

This bioassay method has been applied to fermentation broths of filamentous fungi isolated from marine environments (invertebrates, algae, submerged materials and so on) in Pohnpei and Palau. A new antimitotic component 1 has been isolated from a fungal strain TUF 95F47. We describe here the isolation and fermentation of the fungus and isolation, structure, and biological activity of the compound.

The filamentous fungus, TUF $95 \mathrm{~F} 47$ was isolated from a fallen mangrove branch on the bottom $(-3 \mathrm{~m})$ of a coral reef in Pohnpei during the Pohnpei/Palau expedition by the research vessel Sohgen-maru operated by Marine Biotechnology Institute in 1995. The fungus was isolated from a colony formed from the substrate inoculated on an agar plate ( $1 / 2$ nutrient Potato Dextrose Agar (1/2 PDA) medium, $80 \%$ sea water containing 100 ppm of chloramphenicol) in a clean room on the ship. It was maintained on a slant (1/2 PDA, $50 \%$ sea water) as a stock culture. Identification of the fungus was done in the usual manner using PDA and Oat Meal Agar as media, and TUF 95F47 was identified as a Phomopsis sp. The fungus was cultured for a screening assay with $1 / 2$ nutrient Potato Dextrose (1/2 PD) medium (50\% sea water) in a plate $(15 \mathrm{ml})$ for 3 weeks at $20^{\circ} \mathrm{C}$

Phomopsis sp. strain TUF 95F47 was cultured in ten $500 \mathrm{ml}$ Erlenmeyer flasks (each $100 \mathrm{ml}$ of $1 / 2 \mathrm{PD}, 50 \%$ sea water) for 3 weeks at $20^{\circ} \mathrm{C}$. The curling effect on the mycelia in the bioassay performed as reported ${ }^{2)}$ and was

observed with the broth filtrate. Acetone was added to the cultured broth and filtered. The filtrate was extracted with benzene, and the active component was separated by two consecutive silica gel column chromatographies (benzene - acetone, $2: 1$ and $4: 1$, respectively) and HPLC (ODS, $\mathrm{CH}_{3} \mathrm{CN}-\mathrm{H}_{2} \mathrm{O}=1: 1$ ) to afford $12.0 \mathrm{mg}$ of $1,[\alpha]_{\mathrm{D}}^{27}$ $+31^{\circ}\left(c\right.$ 0.1, MeOH), UV (MeOH) $\lambda_{\max } \mathrm{nm}(\varepsilon): 260$ $(23,000)$.

${ }^{1} \mathrm{H}$ and ${ }^{13} \mathrm{C}$ NMR data for 1 , assigned by ${ }^{1} \mathrm{H}-{ }^{1} \mathrm{H}$ COSY, HMQC, and HMBC spectra, are listed in Table 1. Compound 1 did not give an $(\mathrm{M}+\mathrm{H})^{+}$ion but showed the $(\mathrm{M}+\mathrm{Na})^{+}$ion at $m / z 356$ in the FAB and ESI mass spectra, but the $(\mathrm{M}-\mathrm{H})^{-}$ion was detected at $m / z 329$ in the negative FAB-MS spectrum. The molecular formula, $\mathrm{C}_{21} \mathrm{H}_{30} \mathrm{O}_{3}$, was assigned from the negative HR-FAB-MS $\left[(\mathrm{M}-\mathrm{H})^{-}, m / z 329.2121(\Delta-0.4)\right]$ and NMR data. The ${ }^{1} \mathrm{H}_{-}{ }^{1} \mathrm{H}$ COSY spectra of 1 revealed the connectivity of carbons 2 to $6,19-8-7-12-11-10$, and 17-18. ${ }^{1} \mathrm{H}$ couplings between $\mathrm{H}-12$ and 13 , and $\mathrm{H}-6$ and 15 were very small $(J=\sim 0 \mathrm{~Hz})$. The skeletal structure of 1 was finally elucidated by the analysis of $\mathrm{HMBC}$ and NOESY spectral data as listed in Table 1.

The relative stereochemistry of $\mathbf{1}$ was assigned from ${ }^{1} \mathrm{H}$ NMR and NOESY data (Table 1). Two double bonds at the 2 and 4 positions were determined to have $E$ orientations from the ${ }^{1} \mathrm{H}$ coupling constants, 15.2 and $15.0 \mathrm{~Hz}$, respectively, and $E$-orientation at $\Delta^{16}$ was assigned from the NOE observed between $\mathrm{H}-17$ and 15 . The signal at $\delta 3.57$ (H-11) showed coupling constants of $11.2 \mathrm{~Hz}$ with $\mathrm{H}-10 a, 4.6 \mathrm{~Hz}$ with $\mathrm{H}-10 e$, and $4.6 \mathrm{~Hz}$ with $\mathrm{H}-12$, which revealed that the configurations of $\mathrm{H}-11$ and $10 a$ are axial and that $\mathrm{H}-10 e$ and 12 are equatorial.

Fig. 1. Structures of phomopsidin (1) isolated from Phomopsis sp. strain TUF 95F47 and MK8383 (2).

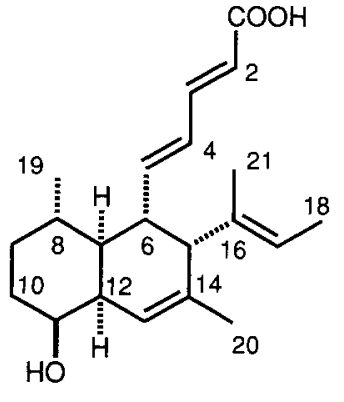

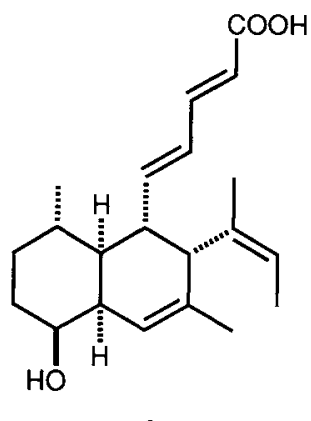


Table 1. ${ }^{1} \mathrm{H}(500 \mathrm{MHz})$ and ${ }^{13} \mathrm{C}$ NMR $(125 \mathrm{MHz})$ data for 1 and 2 in methanol- $d_{4}$.

\begin{tabular}{|c|c|c|c|c|c|c|}
\hline \multirow{2}{*}{$\mathrm{C} \#$} & \multicolumn{4}{|c|}{1} & \multicolumn{2}{|c|}{2} \\
\hline & ${ }^{13} \mathrm{C}$ & ${ }^{1} \mathrm{H}$ & HMBC (C\#) & NOESY (H\#) & ${ }^{13} \mathrm{C}^{\mathrm{a}}$ & ${ }^{1} \mathrm{H}$ \\
\hline 1 & $170.9 \mathrm{~s}$ & - & & & $170.8 \mathrm{~s}$ & - \\
\hline 2 & $120.6 \mathrm{~d}$ & $5.77 \mathrm{~d}(15.2)$ & 1,3 & & $120.8 \mathrm{~d}$ & $5.78 \mathrm{~d}$ \\
\hline 3 & $146.9 \mathrm{~d}$ & $7.18 \mathrm{dd}(15.2,10.2)$ & $1,2,4,5$ & & $146.8 \mathrm{~d}$ & $7.18 \mathrm{dd}$ \\
\hline 4 & $129.0 \mathrm{~d}$ & $6.15 \mathrm{dd}(15.0,10.2)$ & $2,3,5,6$ & 6 & $129.5 \mathrm{~d}$ & $6.16 \mathrm{dd}$ \\
\hline 5 & $148.8 \mathrm{~d}$ & $6.26 \mathrm{dd}(15.0,9.0)$ & $3,4,6$ & 12,21 & $148.3 \mathrm{~d}$ & $6.34 \mathrm{dd}$ \\
\hline 6 & $45.3 \mathrm{~d}$ & $2.78 \mathrm{~m}$ & $4,5,12,13,15$ & 4,19 & $44.7 \mathrm{~d}$ & \\
\hline 7 & $49.3 \mathrm{~d}^{\mathrm{b}}$ & $1.25 \mathrm{~m}$ & 12,13 & $9 a, 11,19$ & solv. ${ }^{c}$ & \\
\hline 8 & $29.9 \mathrm{~d}$ & $1.42 \mathrm{~m}$ & 7,19 & 15 & $30.1 \mathrm{~d}$ & \\
\hline 9 & $34.0 \mathrm{t}$ & $\begin{array}{l}\text { (a) } 1.00 \mathrm{~m} \\
\text { (e) } 1.65 \mathrm{~m}\end{array}$ & $\begin{array}{l}11,19 \\
8,10,11,19\end{array}$ & 7,11 & $34.0 \mathrm{t}$ & 1.02 \\
\hline 10 & $31.1 t$ & $\begin{array}{l}\text { (a) } 1.38 \mathrm{~m} \\
\text { (e) } 1.63 \mathrm{~m}\end{array}$ & $\begin{array}{l}9,11,12 \\
9,11,12\end{array}$ & 13 & $31.0 \mathrm{t}$ & \\
\hline 11 & $73.3 \mathrm{~d}$ & $3.57 \mathrm{~m}(11.2,4.6,4.6)$ & 10,12 & $7,9 a$ & $73.2 \mathrm{~d}$ & $3.61 \mathrm{~m}$ \\
\hline 12 & $39.1 \mathrm{~d}$ & $2.65 \mathrm{~m}$ & & 5 & $39.0 \mathrm{~d}$ & 2.71 br. $\mathrm{s}$ \\
\hline 13 & $124.3 \mathrm{~d}$ & $5.73 \mathrm{~s}\left(J_{12,13}=\sim 0\right)$ & $7,12,14,20$ & $10 a$ & $123.5 \mathrm{~d}$ & 5.72 br. $\mathrm{s}$ \\
\hline 14 & $136.1 \mathrm{~s}$ & - & & & $136.4 \mathrm{~s}$ & - \\
\hline 15 & $51.3 \mathrm{~d}$ & $2.76 \mathrm{~s}\left(J_{6,15}=\sim 0\right)$ & $6,1317,21$ & 8,17 & $43.1 \mathrm{~d}$ & \\
\hline 16 & $136.4 \mathrm{~s}$ & - & & & $136.3 \mathrm{~s}$ & 一 \\
\hline 17 & $123.5 \mathrm{~d}$ & $5.22 \mathrm{q}(6.5)$ & $6,15,16,18,21$ & 15 & $123.9 \mathrm{~d}$ & $5.37 \mathrm{~m}$ \\
\hline 18 & $13.5 \mathrm{q}$ & $1.55 \mathrm{dd}(6.5,0.8)$ & $6,15,16,17,21$ & & $13.5 \mathrm{q}$ & $1.62 \mathrm{~d}$ \\
\hline 19 & $19.4 \mathrm{q}$ & $0.94 \mathrm{~d}(6.5)$ & $7,8,9$ & 6,7 & $19.6 \mathrm{q}$ & $0.97 \mathrm{~d}$ \\
\hline 20 & $22.3 \mathrm{q}$ & $1.60 \mathrm{~s}$ & $13,14,15$ & & $22.3 \mathrm{q}$ & $1.61 \mathrm{~s}$ \\
\hline 21 & $16.8 \mathrm{q}$ & $1.48 \mathrm{~s}$ & $6,15,16,17,18$ & 5 & $22.5 \mathrm{q}$ & $1.54 \mathrm{~s}$ \\
\hline
\end{tabular}

a Reported value $(100 \mathrm{MHz})^{3}$.

b Calibrated from field gradient 2D NMR spectra.

c Overlapped with solvent.

Signals due to $\mathrm{H}-10 e(\delta 1.63)$ and $\mathrm{H}-12(\delta 2.65)$ showed a W-shaped long-range coupling. NOEs were observed between $\mathrm{H}-11 / 7, \mathrm{H}-11 / 9 a, \mathrm{H}-7 / 9 a$, and $\mathrm{H}-7 / \mathrm{H}_{3}-19$. These data showed that $\mathrm{H}-7,9 a$, and 11 are axial, and the configuration of C-19 is equatorial, that is, H-8 is axial. The dihedral angle of $\mathrm{H}-12$ and 13 was assumed to be ca. $90^{\circ}\left(J_{12,13}=\sim 0 \mathrm{~Hz}\right)$, and $\mathrm{H}-13$ showed an NOE with H-10a $(\delta 1.38)$ and a long-range coupling with H-15 $(\delta$ 2.76). An NOE was observed between $\mathrm{H}-15$ and 8 ( $\delta$ 1.42). The configuration of $\mathrm{H}-15$ was, therefore, deduced to be pseudo-axial. The dihedral angle of $\mathrm{H}-15$ and H-6 was shown to be $c a .90^{\circ}$, since the coupling constant was small $\left(J_{6,15}=\sim 0 \mathrm{~Hz}\right)$. NOEs observed between $\mathrm{H}-6 / \mathrm{H}-4$ and $\mathrm{H}-6 / \mathrm{H}_{3}-19$ revealed the stereochemistry at C-6. Consequently, the relative stereochemistry of phomopsidin (1) was assigned as shown in Fig. 1.

The structure of 1 resembled that of MK8383 (2) isolated from terrestrial Phoma sp. as an antifungal component to several phytopathogens ${ }^{3)}$. Although 2 could not be separated from 1 chromatographically, ${ }^{1} \mathrm{H}$ NMR spectra of $\mathbf{1}$ and $\mathbf{2}$ measured by the same instru- ment $(500 \mathrm{MHz})$ clearly distinguished the two compounds. ${ }^{\dagger}$ Reported ${ }^{13} \mathrm{C}$ NMR data for $2^{3, \dagger)}$ listed in Table 1 were very similar to those of $\mathbf{1}$, except for $\mathrm{C}-15$ and 21 , which are consistent with the different stereochemistry at the C-18 methyl group. Compounds 1 and 2 would biogenetically be synthesized via a biological Diels-Alder reaction similar to the biosynthesis of solanapyrones and other decaline derivatives. $\left.{ }^{4,5}\right)$

The microtubule assembly assay using purified porcine brain microtubule proteins was performed as reported previously, ${ }^{6}$ and 1 showed strong inhibitory activity $\left(\mathrm{IC}_{50}, 5.7 \mu \mathrm{M}\right)$. Colchicine and rhizoxin showed $\mathrm{IC}_{50}$ of 10 and $4 \mu \mathrm{M}$, respectively, in the same experiment. Structurally similar compounds, fusarielins, possessing a trans-decaline moiety, did not show any inhibitory activity ${ }^{6)}$ The cis-decaline structure may, therefore, be important to the activity. It is suggested that MK8383 (2) shows similar activity to 1 .

\section{Acknowledgment}

This work was supported in part by Grants-in-Aid for

${ }^{\dagger}$ The authentic sample of MK8383 (2) and the ${ }^{13} \mathrm{C}$ NMR, ${ }^{1} \mathrm{H}-{ }^{1} \mathrm{H}$ and ${ }^{1} \mathrm{H}^{1}{ }^{13} \mathrm{C}$ COSY and $\mathrm{HMBC}$ spectra were provided by Meiji Seika Kaisha, LTD. The ${ }^{1} \mathrm{H}$ NMR spectrum of 2 was measured to compare directly with that of 1. 
Scientific Research from the Ministry of Education, Science, Sports and Culture $(07680625,08680628$, and 08266220) to M.N. and the Sasakawa Scientific Research Grant from The Japan Science Society to T. Y. We thank Drs. S. MrYaCHI, M. ENDO, and Y. SHIZURI of Marine Biotechnology Institute, Inc. for our participation in the Pohnpei/Palau Expedition by Sohgen-maru and Meiji Seika Kaisha, LTD. for the authentic sample and the NMR spectra of 2.

\section{Michio Namikoshi* HISAYOSHI KOBAYASHI ${ }^{a}$ TAKESHI YOSHIMOTO TSUYOSHI HoSOYA ${ }^{b}$}

Department of Ocean Sciences,

Tokyo University of Fisheries,

Minato-ku, Tokyo 108, Japan

${ }^{a}$ Institute of Molecular and Cellular Biosciences, The University of Tokyo,

Bunkyo-ku, Tokyo 113, Japan

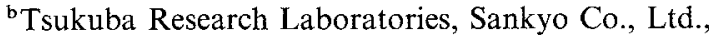

33 Miyukigaoka, Tsukuba, Ibaraki 305, Japan

(Received June 5, 1997)

\section{References}

1) Gerwick, W. H.; P. J. Proteau, D. G. Nagle, E. Hamel, A. Blokhin \& D. L. SLAtE: Structure of curacin A, a novel antimitotic, antiproliferative, and brine shrimp toxic natural product from the marine cyanobacterium Lyngbia majuscula. J. Org. Chem. 59: 1243 1245, 1994

2) Kobayashi, H.; M. Namikoshi, T. Yoshimoto \& T. YoKoCHI: A screening method for antimitotic and antifungal substances using conidia of Pyricularia oryzae, modification and application to tropical marine fungi. $J$. Antibiotics 49: 873 879, 1996

3) Wakui, F.; K. Harimaya, M. Iwata, R. Sashita, N. Chiba \& T. Mikawa (Meiji Seika Co.; Mitsubishi Kagaku K.K.): Dicyclic carboxylic acid MK8383, its manufacture with Phoma spp., and the use as agrochemical microbicides. Jpn. Kokai Tokkyo Koho JP 07,126,211, May 16, 1995, Appl. Oct. 29, 1993; Chem. Abstr. 123: $105272 \mathrm{~b}, 1995$

4) Oikawa, H.; K. Katayama, Y. Suzuki \& A. Ichihara: Enzymatic activity catalysing exo-selective Diels-Alder reaction in solanapyrone biosynthesis. J. Chem. Soc., Chem. Commun. 1995: 1321 1322, 1995

5) IChiHara, A. \& H. Oikawa: Biosynthesis of phytotoxins from Alternaria solani. Biosci. Biotech. Biochem. 61: $12 \sim 18,1997$

6) Kobayashi, H.; R. Sunaga, K. Furihata, N. Morisaki $\&$ S. IWASAKI: Isolation and structures of an antifungal antibiotic, fusarielin A, and related compounds produced by a Fusarium sp. J. Antibiotics 48: 42 52, 1995 